\title{
The Normativity of the Russian Language in the light of Ecological Linguistics and Social Processes in Contemporary Russian Society
}

\author{
E. G. Kulikova \& L. A. Brusenskaya \\ Rostov State University of Economics, 69 Bolshaya Sadovaya Str., Rostov-on-Don, 344002, \\ Russia.Email:kulikova_ellaz1@mail.ru
}

Received February 10, 2017; Revised March 16, 2017; Accepted March 17, 2017; Published May 5, 2017.

\begin{abstract}
Normative mechanisms in modern Russian society have been intensively changed, and this creates a real problem for the normalization process. The study of this problem refers to the current problems of the norm theory. The article is devoted to the investigation of normativity in the light of ecological linguistics, the origins of normativity and the principles of normativity valuation. Destabilizing factors in the development of the modern Russian language, according to the authors of the article are manipulation, verbal aggression as well as excessive foreign borrowings, slang, which displace native words of the literary language, which have a huge linguistic and cultural potential and convey important ethical concepts. Regulatory processes are being considered from the point of view of language-homeostasis that gives an opportunity to value some phenomenon as constructive or destructive one in terms of ability to survive.
\end{abstract}

Keywords: language ecology, linguistic ecology, language norm, rhetorical norm, the modern communicative situation, substandard, borrowing

\section{Introduction}

Social processes of last decades actually led to so-called environmental crisis of the Russian language (Epstein, 2006; Khazagerov , 2012; Skovorodnikov, 2013). The environmental crisis of the Russian language is manifested in the impoverishment of verbal communication in Russian, in the rapid reduction of vocabulary employment not only by some social groups of native speakers, but in reducing the national vocabulary as a whole. Most of the "acquisitions" of the Russian language in recent years are not from the native language. The ecological crisis of the Russian language cannot be overcome without intensive discussion of all of these "touchy subjects".

Ecology is the science studying all the contacts between living organisms and the world around them with the environment. At the end of the $20^{\text {th }}$ century, cultural and historical values have resulted in the emergence of new terminological combinations: the ecology of culture, ecology of morality, ecology of thinking, ecology of history (Zayats and Posukhova2013), ecology of ethics and aesthetics, and ecology of the word, ecology of the language, and finally - the linguistic ecology. The concept of linguistic ecology is widely applied to dying, vanishing languages. This term has become increasingly used in connection with the issues of the destruction of balance in the language and culture, with the spread of invective vocabulary, expanding the scope of its usage. Therefore the linguistic ecology is of great social, cultural, and moral significance. Speech

(c) AesthetixMS 2016. This Open Access article is published under a Creative Commons Attribution Non-Commercial 4.0 International License (http://creativecommons.org/licenses/by-nc/4.o/), which permits non-commercial re-use, distribution, and reproduction in any medium, provided the original work is properly cited. For citation use the DOI. For commercial re-use, please contact editor@rupkatha.com. 
culture, based on the rhetorical canon are interpreted from ecological point of view as a part of healthy, productive environment of a modern person.

The language ecology tries to present an objective picture of the language state, to assess it properly, to draw attention to the dangers and to suggest possible means of enhancing and saving of the language resources. It is important to follow ecological principle (which is known to be formed in medicine - "do no harm"). In the context of ideas of linguistic ecology the mass education of people who speak the language, the fostering language community with good skills of speech, communication culture, the maintaining the communicative space in general are understood as a common welfare for native speakers (Brusenskaya, 2012). The present article, in addition to linguistic aspects, is also performing this social function.

Language is the only thing that can enrich the consciousness with the available common senses, it is the only factor making citizens close to each other. Neither political nor religious ideology can unite our society. Unity has been given to us in the common language.Under the dominant idea of norms plurality and orientation to their non-rigid codification, there is the notion of undermining the norms of the literary language, serious and even dangerous condition in modern Russian literary language (Brusenskaya and Kulikova, 2016; Korosteleva, 2015).

Some scholars consider that fiction is losing its function to form language norm instead of this the mass media is establishing language criteria now (Neshimenko, 2001; Khazagerov, 2003; 2013; Kulikova and Kuznetsova, 2015; Rampton, 2006), the issue of the real possibility of maintaining standards with mass media remains open. The change of social and information contexts in which the process of norms formation is going on requires the extension of the context of norm category investigation.

\section{Methods}

Work methodology is based on the combination of pan chronic (implying the use of speculative, logistic, scholastic methods) and diachronic (implying an appeal to empirical data with wider use of extra-linguistic reality) approaches to the language. Consequently, the leading method is an extrapolation of language theories emerged in certain historical environment to the circumstances of a new historical reality.

\section{Results}

The basis of regulatory submissions is based on two fundamentally different approaches: modern approach, connected with the idea of variance and describing language (including stylistic and communicative) norm, and the ancient one associated with the representation of the anomaly on the basis of metaphase (converting form) and describing the rhetorical norm. The difference between these two approaches is fundamental. The difference between the language norm and the rhetorical one is fundamental, too.

Modern views on deviation as "other rule", "norms liberalization", preference of non-rigid codification, etc. indicate the pressure of rhetorical norm onto the language one (Khazagerov, 2011; 2012; 2015), that is especially noticeable in relation to communicative norm. Such position is mirror-symmetrical to the normative theories of rhetoric (e.g., rhetoric of classicism) which was influenced by the language norm. 
The unequal strength of norms demonstrates different speed of information exchange between the environment and different subsystems of the same system. Functionally it is like the renewal of the living organism cells or personnel rotation in the institution. It is necessary to maintain each subsystem, its cultivation. If cultivation is not possible, collapse of a subsystem or the entire system occurs.

The "imperative" nature of the legal norms and variability, fluctuation and variability of language norms are in some contradiction, and as a result the linguists are often not able to reach any definite and final "verdict". Apparently, in order to characterize the pragmatic aspects of normativity it is legitimate to introduce one more type of norm, i.e. ethical-speech norm.

Codification is the final result of the language reflection, and the question whether this is professional reflection or not, whether it has institutional forms, if it is represented in texts or disparate statements should probably be solved in different ways in each historical case.

It is advisable to consider the level of language reflection (for example, connotation of language phenomena) as a part of the language situation. Forms of language reflection, their character is an important subsystem of language activity.

\section{Discussion}

Recently a special type of norms has been actualized. This type of norm is associated with the concept of communication ethics - the ethic-linguistic (or ethico-linguistic) norm. Ethical standards include such things as kindness, compassion, honesty, unselfishness, caring, respect for people, etc. In the communication process, these properties are manifested as politeness, tact, sensitivity, correctness, delicacy, courtesy, modesty, sincerity. They eliminate rude, aggressive behavior that makes communication ineffective, leads to interpersonal conflicts and has a negative impact on emotional and psychological state of communicants.

Ethic-linguistic norm violation is often associated with the fact that the communicants do not consider pragmatic co-meaning of the word. Lexical meaning is multi-tiered, in addition to the actual semantic content, has pragmatics in the broadest sense of the term. Pragmatics is connected with cultural component of lexical semantics. The present point of view, according to

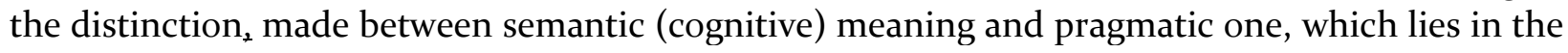
lexical-semantic field of the general word meaning, became well-known, and textbooks addressed to students demonstrate the definitions of pragmatic meaning. Pragmatic meaning is information expressed and got with signs about subjective, connotative emotional attitude of the speaker to the subject, which has a verbal designation, and to the word itself. Thus, pragmatics is primarily correlated with the connotative component of lexical semantics, and non-verbal, implicit meanings help the word to absorb new revelation of thought.

Not only linguistic understanding of the lexical norm itself is important in the context of linguistic ecology, because the use of words is inseparable from the categories of ethics. A.P. Skovorodnikov (2013) speaks even about the discipline of linguistic ethics. Of course, many ethical and linguistic norms are observed by people intuitively, without special study of these norms. It is impossible to tell "good morning" to the person, who had misfortune that day.

A.P. Romanenko suggests that mass media "constantly cultivates festive, upbeat mood", the most popular words "having an entertainment-silly semantics" (Romanenko, 2007, P. 515). 
The more normative language the more its status. Nowadays on the contrary in modern communicative environment there is appropriate clarification the more status of a person who speaks language the more normative language is. Language liberty is forgiven to the person with high social status, but it is unforgivable for others.

This will be found quite acceptable, even decent, and expressive. According to A. M. Holomeyenko (2014), samples of the works by authority writers, known in Soviet times, demonstrate how the threshold of permissibility of using of invectives has decreased. Nowadays some famous authors in their texts use words unprintable before without any hone or other ways of euphemization.

The problem of a special kind of human rights - linguistic right - is very relevant today. This right also includes linguistic ecology: according to this right a person should not be in the language environment alien to him/her, which can lead him/her to the fact of suffering communication failure. The violation of linguistic rights results in humiliation and stress that people usually suffer from obscene language, thus, society is obliged to protect "linguoecologic right" of the person, the "linguoecologic right" protection are "duties" of law.

The right to linguistic ecology overlaps and is closely linked to the right of the individual to protect his own honor and dignity. The frequency of lawsuits based on offences of honor and dignity demands close professional cooperation of philologists and lawyers.

One of the main goals of the new discipline of legal linguistics is legal regulation of obscene language. Although these lexical units traditionally (at the beginning of the legal linguistics formation) were in the focus of law linguists, there are still no legal recommendations of their usage. Works studying data from experiments and surveys conducted among native speakers, typological descriptions of situations and spheres of the use of certain language units and frequency, researching Russian linguistic-cultural tradition in their use, the degree of invectives of these words, the classification of obscene expressions on the scale of invectives could be valuable for legal linguistics. But the difficulties related to legal regulation of invective language are connected with the fact that many native speakers think that invective vocabulary performs the natural function, even useful (supposing that the invectives do not demonstrate aggression in society, but on the contrary they help to reduce its breeding, transferring aggression from the field of business into the field of words).

Today the problem connected with the offensive sound of the word, is becoming increasingly important in the legal continuum. But Russian lawyers still do not have enough opportunities to define the legal boundaries of these phenomena: what language unit is definitely offensive and what language unit is justifiable by some conditions (time, place, etc.)

This problem has not been solved even relating to undisputed obscenism.

Pedagogical projection of this problem is very important in the context of linguistic ecology. In this regard, the work by I.A. Sternin (2011) is very demonstrative. The author suggests the following: 1. to develop speech of children; 2 . to explain that profanity is unacceptable not at all, but only in public places; 3. to invent one's own words which may be used instead of obscenism; 4. not to forbid but to allow and to limit.

Pedagogical struggle against the foul language has always been "destroyed" by examples of its usage in the texts of credible writers.

Effectiveness of these words is not questioned, it is clear, however there is a necessity to provide them with formal bans (quite legitimate ones!). 
I.A. Sternin (2011) draws an analogy with the ancient theater. Death, murder were often the subject matter of tragedies, but there was a ban: killing was not supposed to be on the stage.

In everyday life people use the invectives to respond something causing disgust, and in a polemical text the obscenism is used to convey this condition. And since anger of the author is quite righteous, the reader accepts the form in which it is expressed.

Ethical-speech norm is correlated with such important communicative trend, as political correctness. Political correctness is a special deterrent, a way to avoid verbal aggression, the way to avoid verbal agression causing different kinds of conflicts. Of course, elements of political correctness have always existed in any society. That allowed the members of the society to coexist wth each other. It's kind of a voluntary social contract. The negative consequences of such a contract sometimes are dissemination of ambiguous, inaccurate, the use of euphemisms. Euphemisms soften the reaction of the listener, but do not contribute to clarity, precision and unambiguity of expression.

Political correctness requires rethinking and change of language norms, even grammar ones (connected with, for example, the morphological category of gender) and finds artificial normalization useful. Obviously, moderate manifestations of ideas of political correctness are more relevant for environmental principles.

Verbal manipulation is ethical-linguistic norm violation because it is not consistent with the principles of sincere and benevolent attitude to the addressee, as well as with the maxims of quality, completeness and sensitivity. If deliberate deception (e.g. in advertising) is punishable, manipulative techniques are outside legal regulation. The society realizes that "great danger to the public is false advertising, misleading consumers.

Ethical-speech errors occur when the speaker ignores the ethical and aesthetic component of speech culture, which in the Russian speech tradition involves the special role of categories of sensitivity, delicacy, peacefulness, mercy. Knowledge of the rules of speech influence, a clear distinction of its types gives the opportunity to improve the communication process, to eliminate failures and misunderstandings in communication

\section{Conclusion}

There a lot of "pain" points in modern communication: incorrect advertising, unmotivated use of borrowings, manipulative strategies and tactics in political discourse, extremely high level of aggressiveness in the speech behavior of people (everyday conversation, parliamentary debates)

It is clear that verbal aggression reflects a more deep-seated aggressiveness due to its prolonged suppression with external forces, as well as fear of the outside world. A very negative expressivity in disputes, the rigidity in the evaluation of the interlocutor behavior are allowed today, etc. Genre of verbal invective has been intensified. It is based not only on permissible in the literary language means to discredit the opponent, but on the expressive turns of speech that are far beyond the ethical-linguistic norms.

The extent of publicly acceptable speech has been much increased in the minds of the people. The normative space of the modern Russian language has been transformered under the influence of new information technologies and means of communication. Computer communication develops in accordance with the laws of mass culture and the processes of globalization, is a catalyst of manifestation of the expressive potentials of language, leads to the 
formation of new genres, including invective violating ethical and linguistic norms and environmental law on "communicative comfort."

This new phenomenon is due to a combination of all the circumstances of socio-political and cultural life, and without careful study of which it is impossible to give any recommendations in the sphere of normativity in general and ethical-linguistic norms in particular.

Stable norms are important signs of ecological well-being of the language, if they are kept by its speakers. The "health" of the language, all its aspects being the subject of ecological linguistics investigation, is a vital condition for the preservation of the ethnic identity and an important component of national security (Haugen, 1966; Fill, 1998).

\section{Acknowledgements}

The publication has been prepared within the scientific project No. 16-04-00037 supported by Russian Foundation for Humanities

\section{References}

Ahlmann, E. (1926). Das normative Moment im Bedeutugsbegriff «Annales Academiae scienciarum fennicae». Helsinki, ser. B, t. X.

Ashby, W.R. (1957). Introduction to Cybernatics. London: Chapman \& Hall, p. 312.

Brusenskaya, L.A. (2012). What is the Ecological Approach to the Language? News of the Southern Federal University. Philology, 3: 149-156.

Brusenskaya, L.A., \& Kulikova, E.G. (2016). Ecological Linguistics. Rostov-on-Don: Flinta-Science, p. 186.

Cannon W.B. (1963). The Wisdom of the Body: H.Y.: W. Norton \& Company, p. 333

Coseriu, E. (1962). Systema, norma y habla. Montevideo. In Teoria del lenguaje e linguistica general. Madrid.

Epstein, M.N. (2006). The Russian Language in the Light of Creative Philology of Researches. Banner, 1: 196-207.

Fill, A. (1998). Ecolinguistics - State of Art. In Arbeiten aus Anglistik und Amerikanistik. Band 23. Heft 1. Tubingen, pp. 9-28.

Gorbachevich, K.S. (1978). Variability of Speech and Language Norm. Lenigrad: Science, p. 234

Hartmann N. (1949). Das Problem des geistigen Sein. Berlin, p. 564

Haugen, E. (1966). The Ecology of Language. In Haugen, E. Essays. Stanford, CA: Stanford University Press. pp.159-190.

Jacobson, R. (1975). Linguistics and Poetics. Structuralism: for and against. Moscow: Progress, pp. 193-230

Kassil, G.N. \& Ginter, E.C. (1972). Homeostasis. In: The Great Soviet Encyclopedia: Vol. 7. Moscow: Soviet Encyclopedia, pp. 51

Khazagerov, G.G. (2001). System of Persuasive Speech as Homeostasis: Oratorics, Homiletics, Didactics, Symbolism. Sociological Journal, 3, 5-28.

Khazagerov, G.G. (2003). Problems of Language norm in the light of the Concepts of "beautiful", "sublime" and "effective" (to the typology of the norm). In Language in the Pragmalinguistic Aspect: expressive stylistics, rhetoric. Interuniversity Collection of Scientific Essays: (pp. 55-64). Rostov-on-Don: Rostov State University.

Khazagerov, G.G. (2011). Speech Culture in the Conditions of Weakened Norm. News of Southern Federal University. Philological Sciences, 2: 92-99.

Khazagerov, G.G. (2012). Linguistic Reception of Rhetorical Ideas: Fundamental and Applied Aspects. Proceedings of Higher Educational Establishments. The North Caucasus region. Social Sciences, 3: 92-94.

Khazagerov, G.G. (2013). Counterproductive Competence. Higher Education in Russia, 1: 129-134.

Khazagerov, G.G., \& Glushko, M. A. (2015). A Systematic Approach to Qualities of Speech (for example consistency). Humanitarian, Socio-economic, and Social Sciences, 2: 394-399. 
Korosteleva, T.V. (2015). Archaisms as Tropic Means in the Modern Russian Literary Language: Linguopragmatic Aspect: (p. 185). Volgograd: VSPU .

Holomeyenko, O.M. (2014). Cognitive Gender Dominants and Their Language Representations in the "Female Prose". Rostov-on-Don: SFU, p. 182

Kibrik, A.E. (2003) Constants and Variables of the Language. St. Petersburg: Aletheia, p. 719

Krysin, L.P. (2002). Modern Literary Norm and its Codification. The Russian Language at School, 2: 82-87.

Kulikova, E.G. \& Kuznetsova, A.V. (2015). Modern Russia: Communicative Situation under Postmodern Era. Asian Social Science, 11(7): 284-294. DOI:10.5539/ass.v11n7p

Mathesius , V. (1967). On the Need of Stability of the Literary Language. In: Prague Linguistic Circle. Moscow: Progress, pp. 348-386

Neshimenko, G.P. (2001). Dynamics of Speech Standard of Modern Public Verbal Communication: problems, tendencies of development. Questions of linguistics, 1: 98-132.

Pershikov, V.I. \& Savinkov, V.M. (1991). Explanatory Dictionary on Informatics. Moscow: Finance and Statistics, p. 543

Rampton, B. (2006). Language in Late Modernity: Interaction in an Urban School. Cambridge: Cambridge University, p. 443

Romanenko, A.P. (2007). Peculiarities of Modern Verbal Culture. In Language in Motion: To the $70^{\text {th }}$ anniversary of L.P. Krysin : (pp.506-519). M.: Languages of Slavic Culture.

Skovorodnikov, A.P. (2013). On the Subject of Ecolinguistics in Relation to the State of the Modern Russian Language. Language Ecology and Communicative Practice, 13, 194-222.

Sadovski, V.N. (1972). System. In The Great Soviet Encyclopedia. Vol. 23. Moscow: Soviet Encyclopedia, pp. 640-641

Sadovski, V.N. (2001). System. In Philosophical Vocabulary. Moscow: Republic, pp. 513-514.

Shcherba, L.V. (1945). Another Problems of Linguistics. News of the Academy of Sciences of the USSR. Vol. 5 .

Sternin, I.A. (2011). The Problem of Profanity. Voronezh: VGPTU, p. 32

Solntsev, V. M. (1998). Variability. The Russian language. Encyclopedia. Moscow: Great Russian encyclopedia, pp. 6o-61

Solzhenitsyn, A.I. (1990). The Russian Dictionary of the Language Extension. Moscow: Science, p. 272

Vakhek, I. (1967). To the Problem of the Written Language. In: Prague Linguistic Circle. Moscow: Progress, pp. 524-534

Vakhek, I. (1967). Written Language and Printed Language. In: Prague Linguistic Circle. Moscow: Progress, pp. 535-543

Vinokur. G.O. (1929). Culture and Language. Moscow: The Federation, p. 346

Yudin, B.G. (2001). Homeostasis. In Philosophical Vocabulary. Moscow: Republic, pp. 130

Zayats, P. V., \& Posukhova, O. Y. (2013). Engineering of Political Party Systems: Experience of the Methodological

Designing. World Applied Sciences Journal, 26(12): 1628-1632. 